Edukacja Filozoficzna 68/2019

ISSN 0860-3839

DOI: $10.14394 /$ edufil.2019.0017

ORCID: 0000-0001-8900-0901

\title{
Echad i ahawa, ajin i jesz. Wybrane koncepcje kabalistyczne w Gwieździe zbawienia Franza Rosenzweiga
}

\author{
Katarzyna Kornacka \\ (Uniwersytet im. Adama Mickiewicza w Poznaniu, \\ Instytut Kultury Europejskiej)
}

Z Wszystkiego wycofała się Jedność. Porównywalna do dzieła sztuki, była ona na zewnątrz pojedynczym Jednym, a tylko jeszcze wewnątrz Wszystkim. W ten sposób pozostawiła miejsce obok siebie ${ }^{1}$.

Franz Rosenzweig

\section{Wprowadzenie}

Na początku było Wszystko, na początku była Nicość, na początku było „Tak”, na początku było „Nie”2 i na początku była miłość, rozumiana nie jako byt, pojęcie czy własność, lecz jako „wydarzenie”3, pozbawione jakiegokolwiek desygnatu, a zatem nieuchwytne i niewyrażalne ${ }^{4}$ Miłość - „samoprzeobrażenie, zaparcie się

\footnotetext{
1 F. Rosenzweig, Gwiazda zbawienia, tłum. T. Gadacz, Wydawnictwo iTON Society, Warszawa 2012, s. 67.

2 Tamże, s. 87.

3 Tamże, s. 278

4 Por. tamże, s. 332.
} 
siebie" aktów kreacji, podejmowanych przez Nicość nie będącą pustką lub próżnią, lecz stanowiącą „samozaprzeczającą się Nicość Boga”. W wyniku stwarzania - czyli współdziałania energii „Tak” oraz siły „Nie” - rozpada się całość Wszystkiego, ponieważ „Jedność wycofuje się ze Wszystkiego”. Pozostawiając „miejsce obok siebie", zaczyna transcendować opuszczone Wszystko. Wyłaniają się trzy odrębne porządki - trzy rzeczywistości: Boga, człowieka i świata. Najpierw bytują niezależnie, jako „Sobości”, a następnie - w rezultacie objawienia, którego pierwszym etapem jest właśnie stworzenie - stają się wzajemnie uwikłane, trwając odtąd w dynamicznych oraz ścisłych relacjach ${ }^{7}$. Oczywiście okoliczniki czasu, które zastosowałam w powyższym zdaniu, a także przydawka „pierwszy”, przed słowem „etap” nie powinny być odczytywane literalnie. W tak ujmowanym akcie kreacji nie istnieje ani „najpierw”, ani „następnie”, ani „wcześniej”, ani „później”, ani „przed”, ani „po”. Czas Boga płynie odmiennie niż czas świata. ${ }^{8}$. Zarówno stwarzanie, jak i objawianie dzieją się ustawicznie, aktualnie, pozostając w stosunku do siebie synchronicznymi oraz równoległymi procesami ${ }^{9}$. Tym samym wciąż „teraźniejszy” i nieustannie „wydarzający się” jest także sam Bóg ${ }^{10}$ : analogicznie do miłości, której „istotą jest chwila”11.

W powyższy sposób można najkrócej, jak sądzę, scharakteryzować podstawowe założenia kosmologiczne i ontologiczne, zaprezentowane przez Franza Rosenzweiga w jego najważniejszym dziele, czyli Gwieździe zbawienia. Jeden stał się w pewnej chwili odrębny od Wszystkiego, Jeden jest specyficznie pojmowaną Nicością (Nie-Czymś), a miłość Jednego wciąż na nowo się wydarza, inicjując oraz warunkując wiecznotrwałe dzieło kreacji tego, co istniało, istnieje albo zaistnieje. Nicość konotuje nieokreśloną, nienazywalną i niewymawialną boskość - Bożą moc lub energię. Miłość natomiast ma być afektem odczuwanym przez „Jednego, będącego ponad całością"12 - Boga, o którym można już powiedzieć, że odczuwa miłość, czyli orzec, iż „jest Kochający”. Powodowany uczuciem zapragnął i nadal pragnie stwarzać świat oraz bytującego w świecie człowieka, czyniąc go odpowie-

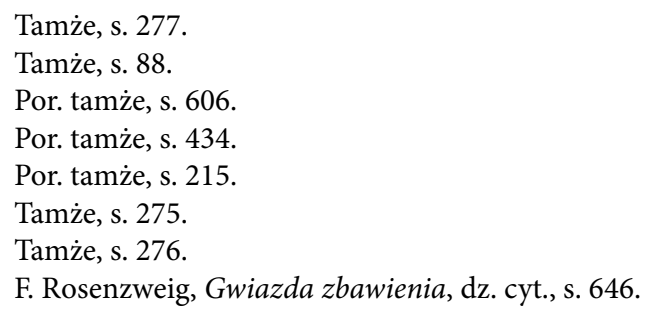


dzialnym za dzieło kreacji. Pokreślić też należy, że - według Rosenzweiga - przed nadejściem „chwili”"13, w której „zdarzyła się” miłość, nie istniał jeszcze żaden byt odrębny od Wszystkiego-Całości, ponieważ Wszystko trwało wraz z Jednym, dopóki Jeden niespodziewanie nie pokochał. Zapragnął wówczas podzielić się istnieniem, negując i wyrzekając się siebie, potem zaś nawiązał relację z Ty świata i Ty człowieka.

Kiedy analizujemy przytoczone powyżej poglądy, zwracamy przede wszystkim uwagę na ich koherencję. Dostrzegamy, z jak wielkim zaangażowaniem stara się Rosenzweig eksponować ideę miłującej oraz udzielającej samą siebie Transcendencji ${ }^{14}$, a także podkreślać ontologiczną odrębność Boga i człowieka, zapewniającą ludziom wolność oraz autonomię wobec Absolutu. Absolut z kolei, paradoksalnie, staje się w doktrynie Rosenzweiga zależny od ludzi, chociażby - bądź aż - z tego powodu, że ich kocha ${ }^{15}$. Z drugiej strony natomiast pojawić się musi pytanie, czy stworzony przez Rosenzweiga „system” jest wynikiem jego osobistego namysłu, czy też urodzony w Kassel filozof ${ }^{16}$ od kogoś lub skądś zapożyczył istotne elementy swojej myśli. Osobiście jestem przekonana, że za prawdziwy należy uznać drugi człon tej alternatywy, ponieważ - w moim odczuciu - wiele motywów i koncepcji ściśle łączy poglądy Rosenzweiga z doktrynami kabały zoharycznej i luriańskiej, wypracowanymi przez kabalistów żydowskich w trzynastowiecznej Kastylii, a następnie w szesnastowiecznym Safedzie. Fakt ten jest poniekąd zaskakujący, ponieważ zachowały się zdecydowanie negatywne wypowiedzi Rosenzweiga na temat kabały ${ }^{17}$. Sądzę jednak, że krytykując myśl mistyczną, filozof miał raczej na myśli siedemnastowieczną oraz osiemnastowieczną „kabałę heretycką" ${ }^{\prime 18}$, tworzoną przez mekubalim, zwłaszcza przez saba-

\footnotetext{
Tamże, s. 277.

Por. tamże, s. 70.

Por. J. Guttmann, Philosophies of Judaism: The History of Jewish Philosophy from Biblical Times to Franz Rosenzweig, Anchor Books, tłum. D.W. Silverman, Garden City, NY 1966, s. 440.

16 W kwestii biografii oraz myśli Franza Rosenzweiga - zob. np. N.N. Glatzer, Franz Rosenzweig: His Life and Thought, Hackett Publishing Company, Indianapolis, IN, Cambridge, MA 1998; B. Pollock, Franz Rosenzweig and the Systematic Task of Philosophy, Cambridge University Press, New York, NY 2014; E.R. Wolfson, Giving beyond the Gift: Apophasis and Overcoming Theomania, Fordham University Press, New York, NY 2014, s. 34-89; J. Guttmann, Philosophies of Judaism: The History of Jewish Philosophy from Biblical Times to Franz Rosenzweig, dz. cyt., s. $416-449$.

17 Por. M. Idel, Old Worlds, New Mirrors: On Jewish Mysticism and Twentieth-Century Thought, University of Pennsylvania Press, Philadelphia, PA 2010, s. 166.

18 G. Scholem, Kabała i jej symbolika, tłum. R. Wojnakowski, Warszawa 2014, s. 131.
} 
tian i frankistów ${ }^{19}$. W tamtym czasie - epoce fałszywych mesjaszy - żydowska myśl mistyczna stała się bez wątpienia anomijna, a także w istocie zaczęła ewoluować w niebezpiecznym kierunku, powodując ostatecznie, że tysiące wyznawców judaizmu dokonało konwersji na islam oraz chrześcijaństwo, choć ta akurat sytuacja stanowiła nieprzewidziany i szkodliwy „skutek uboczny” mistycznych uniesień, a także żydowskiej tęsknoty za bezpiecznym, spokojnym i sprawiedliwym światem ${ }^{20}$.

Nie dziwi zatem, że Rosenzweig, który sam w pewnym momencie zamierzał zostać chrześcijaninem, lecz ostatecznie zrezygnował z konwersji ${ }^{21}$, przynajmniej oficjalnie dystansował się od kabalistycznych doktryn będących, jego zdaniem, przyczyną licznych aktów apostazji, które miały miejsce w XVIII i XIX wieku. Jednocześnie był w stanie, jak uważam, przeprowadzić dystynkcję pomiędzy wieloma nurtami współistniejącymi w ramach żydowskiego mistycyzmu. Bądź też, inaczej tę kwestię ujmując, jestem przekonana, że Rosenzweig bez trudu odróżniał „kabałę zoharyczną” oraz „system safedzki” od myśli chasydzkiej lub od nauczania chociażby Natana z Gazy, określanego jako prorok „mesjasza” Szabtaja Cwiego.

Nie można też zapominać, że Rosenzweig był doktorem filozofii, a jego dysertacja została poświęcona myśli politycznej Georga Wilhelma Friedricha Hegla ${ }^{22}$. Hegel zaś, na co wskazują niektórzy historycy filozofii, stosunkowo dobrze znał myśl kabalistyczną ${ }^{23}$, dzięki - między innymi - lekturze pism Jakuba Böhmego oraz Friedricha Schellinga ${ }^{24}$. Co więcej, w drugim tomie heglowskich Wykładów z historii filozofii odnajdujemy poświęcony kabale fragment, w którym niemiecki

19 Termin „mekubalim” oznacza „tych, którzy posiedli sekretną, tajemną wiedzę”, czyli nie tylko znają ogólną doktrynę kabalistyczną, lecz także zostali „wtajemniczeni” w doktryny najbardziej ezoteryczne. W XVIII i XIX stuleciu do kręgów mekubalim zaliczali się chasydzi, sabatianie i frankiści, a także zwolennicy Gaona Wileńskiego, będącego w tamtym czasie przywódcą mitnagdim, tj. przeciwników chasydyzmu.

20 Por. J. Doktór, Początki chasydyzmu polskiego, Wydawnictwo Naukowe Uniwersytetu Mikołaja Kopernika, Toruń 2017, s. 181.

21 Por. N.N. Glatzer, Franz Rosenzweig: His Life and Thought, dz. cyt., s. 23-31.

22 Por. F. Rosenzweig, Hegel und der Staat. Herausgegeben von F. Lachmann. Mit einem Nachwort von A. Honneth, Suhrkamp Verlag, Berlin 2010.

23 Por. S.L. Drob, The Sefirot: Kabbalistic Archetypes of Mind and Creation, URL: https://link.do/ QGmeI, [dostęp: 25.04.2019].

24 W tej kwestii - zob. np. F. Kwiatkowski, Problem wplywu teozofii Jakuba Böhmego na idealistyczny system Georga Wilhelma Fryderyka Hegla, „Studia z Historii Filozofii” 2016, nr 3(7), s. 55-71. Z kolei związki myśli Rosenzweiga z doktryną Schellinga omawia Yudit Kornberg-Greenberg (Y. Kornberg-Greenberg, Better than Wine: Love, Poetry, and Prayer in the Thought of Franz Rosenzweig, Scholars Press, Atlanta, GA 1996, s. 41 i nn.). 
filozof przedstawia - wprawdzie w dużym skrócie i uproszczeniu - podstawowe koncepcje sformułowane o wiele wcześniej przez żydowskich mistyków ${ }^{25}$. Jednocześnie sam Rosenzweig w liście z roku 1917, skierowanym do Hermanna Cohena, wyraża nadzieję, że pod koniec studiów będzie mógł uczestniczyć w zajęciach poświęconych kabale luriańskiej oraz Sefer ha-Zohar, napisanej w Hiszpanii Księdze blasku, która stała się Bibliq wszelkich mekubalim późniejszych epok ${ }^{26}$.

Można więc chyba postawić tezę, że Rosenzweig już jako młody człowiek interesował się myślą mistyczną i dążył do jej poznania. Jego „nowe myślenie”27 zostało ukształtowane przez stare doktryny, głoszące współzależność Boga i człowieka, a także wskazujące na istnienie ścisłego związku pomiędzy wymiarem ontycznym a etycznym rzeczywistości. Niektóre $\mathrm{z}$ tych doktryn postaram się w swoim artykule omówić, dowodząc, iż znalazły aprobatę Rosenzweiga i zostały przez niego wykorzystane do konstrukcji „gwiaździstego systemu”. Przyniósł on współczesnemu filozofowi sławę nieporównywalnie większą od tej, którą cieszyli się tak znani i wybitni kabaliści, jak na przykład Szymon bar Johaj, Mojżesz z Leonu, Mojżesz Kordowero, „boski Ari” - Izaak Luria z Safedu, Eliasz de Vidas czy wreszcie Chaim Vital, autor przełomowego dla kosmologii i ontologii kabalistycznej traktatu Ec Chaim, czyli Drzewo $\dot{z} y c i a^{28}$, zawierającego pierwszy opis boskich pra-słów „Tak” i „Nie”, autonegacji i emanacji, określanych odtąd przez mistyków jako cimcum i szefa. W języku Rosenzweiga są natomiast wyrażone jako „zaparcie się siebie”29 i „obdarowywanie” ${ }^{30}$. Warunkują także stały proces kreacji, postrzeganej przez filozofa jako etap wciąż aktualizowanej historii objawienia. Genezą tego procesu ma być, według Rosenzweiga, miłość „potężna jak śmierć” ${ }^{31}$.

25 G.W.F. Hegel, Wykłady z historii filozofii, t. 2, tłum. Ś.F. Nowicki, Wydawnictwo Naukowe PWN, Warszawa 2013, s. 512-515.

26 F. Rosenzweig, Kleinere Schriften, Schocken Verlag, Berlin 1937, s. 66. Por. M. Idel, New Worlds, New Mirrors: On Jewish Mysticism and Twentieth-Century Thought, dz. cyt., s. 162.

27 Por. F. Rosenzweig, Nowe myślenie. Kilka uwag ex post do Gwiazdy zbawienia, w: tegoż, Gwiazda zbawienia, dz. cyt., s. 659-689.

28 Dzieło znane obecnie jako Ec Chaim zawiera spisane przez Chaima Vitala doktryny sformułowane wcześniej przez Izaaka Lurię. Tekst traktatu opublikowano w kilku wersjach po śmierci Vitala, czyli po roku 1620. Por. D. Wilder-Menzi, Introduction, w: Ch. Vital, The Tree of Life. Chayyim Vital's Introduction to the Kabbalah of Isaac Luria: The Palace of Adam Kadmon, tłum. D. Wilder-Menzi, Z. Padeh, Arizal Publications, New York, NY 2008, s. xlix.

29 F. Rosenzweig, Gwiazda zbawienia, dz. cyt., s. 277.

30 Tamże, s. 275 i nn.

31 Tamże, s. 332. 


\section{Miłość jako nadrzędna przyczyna sprawcza boskich aktów kreacji}

Sama miłość nie wie, czy będzie kochać, a nawet, czy kochała. Wystarczy, gdy wie to jedno, że kocha ${ }^{32}$.

Franz Rosenzweig

W Gwieździe zbawienia Rosenzweig pisze wiele na temat miłości. Badacze jego myśli dosyć często omawiają więc tę problematykę, uznając poglądy żydowskiego dialogika za interesujące, oryginalne i ważne ${ }^{33}$. Do pewnego stopnia można się zgodzić z taką interpretacją, ponieważ według Rosenzweiga miłość Boga do tego, co stworzone, pełni funkcję istotną ontologicznie. Przyczynuje istnienie wszystkiego, co jest od Boga odrębne i co powstaje wyłącznie dzięki mocy Jego pozytywnego uczucia, które jednak nie jest „wszechogarniające”, lecz zawsze skierowane ku konkretnemu bytowi ${ }^{34}$. Jak bowiem zauważa Rosenzweig, „miłość nie jest wszechmiłością” ${ }^{35}$, a „objawienie nie wie nic o 'wszechmiłującym' Ojcu”36. W tym momencie należy przyznać, że słowa filozofa brzmią zdroworozsądkowo, o ile odnosilibyśmy je do ludzi. Miłość jest wprawdzie wyjątkowo silnym afektem, ale jej „obiekt” zostaje wybrany spośród innych przez kochający podmiot, uważający „miłowanego” za istotę tak wyjątkową, że niemożliwą do zastąpienia przez jakąkolwiek inną. Nie wydaje mi się również prawdopodobna (ludzka) miłość do wszystkich lub do wszystkiego, skoro wówczas nie byłaby już miłością per se, lecz raczej jednym z atrybutów przypisywanych miłości i jej współtowarzyszących: na przykład życzliwością, lojalnością czy szacunkiem. Mogę bowiem starać się szanować wszystkich, lecz nie jestem w stanie wszystkich pokochać. Dlatego zgadzam się z autorem Gwiazdy zbawienia, który wyraża pogląd, że „miłość dotyczy zawsze tylko dwojga, zna tylko Ja i Ty, nie zaś ulicę"37. Z drugiej strony nie twierdziłabym tak autorytarnie jak Rosenzweig, że miłość Boża nie jest

\section{Tamże, s. 278.}

33 W tej kwestii - zob. np.: Y. Kornberg-Greenberg, Better than Wine: Love, Poetry, and Prayer in the Thought of Franz Rosenzweig, dz. cyt.; C. Welz, Love's Transcendence and the Problem of Theodicy, More Siebeck, Tübingen 2008; M. Bardel, Mocna jak śmierć. Zagadnienie miłości $w$ antropologii filozoficznej Franza Rosenzweiga, Universitas, Kraków 2001.

35 F. Rosenzweig, Gwiazda zbawienia, dz. cyt., s. 278.

36 Tamże, s. 278.

37 Tamże, s. 335. 
„wszechmiłością", ponieważ głosząc taki pogląd, antropomorfizowałabym byt absolutny, a nawet negatywnie definiowałabym Boga, co - jak pozwalam sobie uważać - byłoby raczej absurdalne i pozbawione sensu, przynajmniej z punktu widzenia filozofii. Mimo to właśnie absolutna miłość stała się szczególnie ważnym przedmiotem namysłu Rosenzweiga, który podkreśla przede wszystkim, że afekt Boga do tego, co stworzone, nie wynika z jakiejkolwiek potrzeby Kreatora, będącej genezą Jego uczucia, ponieważ żadna - ani boska, ani ludzka - miłość nie wie $\mathrm{z}$ reguły niczego o swojej przyczynie, nadchodząc albo „wydarzając się” nagle, znienacka, nieoczekiwanie i niespodziewanie. Tak więc „chwila, która ją budzi, jest jej pierwszą chwilą"38.

O znaczeniu miłości wspomina też autor Gwiazdy zbawienia, analizując Pieśń nad Pieśniami ${ }^{39}$. Wydaje się istotne, że jego zdaniem Szir ha-Szirim aszer li-Szlomo należy uznać za najważniejszą część objawienia oraz za „centralną księgę objawienia"40. W tym momencie nasuwa się pytanie: $\mathrm{z}$ jakiego powodu Rosenzweig przypisuje wyjątkowe znaczenie tekstowi Cantici Canticorum? Nie wiem, czy odpowiedź, którą w tym kontekście mogłabym zasugerować, okaże się przekonująca, ale innej nie jestem w stanie udzielić, skoro sama czuję się do niej głęboko przekonana. Uważam, że Rosenzweig zupełnie świadomie i bezpośrednio nawiązuje tu do tradycji kabalistycznej. Pojęcie miłości, określanej w języku hebrajskim przez rzeczownik אהבה (ahawa), niejednokrotnie stawało się kluczowe dla rozważań żydowskich mistyków, którzy bardzo chętnie wykorzystywali w swoich traktatach symbolikę erotyczną i seksualną, prezentując złożone zagadnienia teologiczne, teozoficzne, kosmologiczne i ontologiczne. Według kabalistów istnieje bowiem ścisły związek pomiędzy słowami אהבה (ahawa) - „miłośćc - oraz (echad) - ,jeden”. Każde z nich rozpoczyna pierwsza litera hebrajskiego alfabetu, czyli $\times(\text { alef })^{41}$. Wyrazy posiadają tę samą wartość numeryczną, wynoszącą w obu przypadkach 13. Litera $\times$ reprezentuje zarówno jedność Boga, jak też Jego miłość bądź miłosierdzie wobec tego, co stworzone i stwarzane, ponieważ sefirą Drzewa Życia, symbolizowaną przez $\times$ jest חס (chesed), konotująca Bożą dobroć, łagodność i szczodrość. A zatem można stwierdzić, że w takim kontekście אהבה - miłość, stanowi przypadłość (cechę akcydentalną) אחד - Jedy-

\footnotetext{
Tamże, s. 277.

Tamże, s. 327-336.

F. Rosenzweig, Gwiazda zbawienia, dz. cyt., s. 332.

${ }^{41}$ Por. M.A. Ouaknin, Tajemnice kabały, tłum. K.K. Pruscy, Wydawnictwo Cyklady, Warszawa 2006, s. 282 i nn.
} 
nego, nie będąc jednak atrybutem Boga, skoro zgodnie z nauczeniem kabalistów חסד nie zawsze jest aktywna, a jej działanie zostaje niekiedy podporządkowane przeciwległej, znajdującej się po lewej stronie Drzewa Życia sefirze גבורה (gewura), określanej także jako דין (din), która aktualizuje Bożą surowość, Boży gniew i władzę sądzenia ${ }^{42}$. Twierdząc zatem, że miłość nie „jest”, lecz że „się wydarza”, Rosenzweig powielił w zasadzie doktrynę pojawiającą się już w Księdze Izajasza, następnie zaś rozwijaną, doprecyzowywaną i wyjaśnianą przez kabalistów, starających się odpowiedzieć na pytanie: unde malum? Innymi słowy, zdaniem kabalistów, „tworzący światło i stwarzający ciemności” ${ }^{\text {”3 }}$ Bóg nie jest, lecz bywa „kochający”. Co więcej, sam również pragnie miłości, ponieważ, według kabalistycznego mitu, podczas prekosmicznego dramatu szewirat ha-kelim ${ }^{44}$ miał utracić męsko-żeńską jedność ${ }^{45}$, o czym wzmiankuje expressis verbis także Rosenzweig $^{46}$. Cierpienie bóstwa pociąga za sobą ważne implikacje antropologiczne, etyczne i ontologiczne. Tylko wówczas bowiem, gdy ludzie postępują w sposób prawy, czyniąc dobro, Szechina - żeński aspekt bóstwa - może powracać z wygnania (galut ha-Szechina) do Kudsza BerichHu, „Świętego, Niech Będzie Błogosławiony”, Króla i Oblubieńca, następnie zaś łączyć się z Nim w miłosnym akcie, warunkującym stwarzanie oraz podtrzymywanie bytów jednostkowych $\mathrm{w}$ ich już trwającym istnieniu ${ }^{47}$. Jednocześnie kiedy Rosenzweig podkreśla, że każda miłość, w tym również miłość Boga, „jest zmysłowo-nadzmysłowa”"48, ponownie zbliża się do doktryny mistycznej. W Sefer ha-Zohar napisano przecież wyraźnie:

Nauczyliśmy się, że ten świat jest odbiciem wyższego świata i że wszystko, co istnieje na tym świecie, istnieje w świecie wyższym [...]. Posłuchaj, czego

42 Por. tamże, s. 244.

43 Iz 45, 7. Cytaty biblijne podaję za: Biblia Tysiąclecia - Pismo Święte Starego i Nowego Testamentu w przekładzie z języków oryginalnych, Wydawnictwo Pallotinum, Poznań, Warszawa 1980.

44 W piśmiennictwie kabalistycznym dramat ten bywa niekiedy określany jako „upadek światów”, nefilat ha-olamot, bądź jako „śmierć królów”, mitat ha-melachim. Por. R. Elior, Między galutem a wyzwoleniem, między rzeczywistościq a kabała. Esej o chasydyzmie, tłum. D.M. Ben Refael, Wydawnictwo Naukowe Contact, Poznań 2019, s. 28.

45 Por. G. Scholem, Kabała i jej symbolika, dz. cyt., s. 152-157.

46 Por. F. Rosenzweig, Gwiazda zbawienia, dz. cyt., s. 635-638.

47 W tej kwestii - zob. np. G. Scholem, O mistycznej postaci bóstwa, tłum. A.K. Haas, Warszawa 2010, s. 207-209; J. Langer, Miłosna mistyka kabały. Światy, słowa, sny, tłum. L. Jerkiewicz, Kraków 2015; R. Patai, The Hebrew Goddess, Detroit, MI 1990, s. 265-276, M. Idel, Kabbalah and Eros, Yale University Press, New Haven, CT 2005.

48 F. Rosenzweig, Gwiazda zbawienia, dz. cyt., s. 331. 
się nauczyliśmy: wszystko, co Jedyny, Niech Będzie Błogosławiony, stworzył w górze i na dole, zawiera się w tajemnicy mężczyzny i kobiety ${ }^{49}$.

Okazuje się zatem, że nie bez powodu filozof uznał Szir ha-Szirim za najistotniejszą partię Tory. Tekst Pieśni nad Pieśniami można przecież odczytywać bądź dosłownie - jako poemat o (również fizycznej) miłości pięknej Sulamit i jej ukochanego, Pasterza i Króla - bądź alegorycznie - jako opis miłości Boga do Jego Narodu, do córy Syjonu i (mistycznego) Zgromadzenia Izraela. Niezależnie od przyjętego sposobu egzegezy Pieśni, podczas jej analizy zwracają uwagę zarówno poetyckie frazy wyrażające zmysłowe pożądanie, jak i wypowiedzi, w których pobrzmiewa subtelna - będąca wyrazem "nadzmysłowości” - czułość. Przysłaniając sobą pożądanie, unosi się ona ponad „tajemnicą mężczyzny i kobiety”, których sekretna bliskość staje się paradygmatem wszelkiego - w tym również boskiego - stwarzania, zgodnie ze słowami Zoharu.

Filozof przedstawia ten problem oraz odsłania „tajemnicę”, posługując się wieloma metaforami. Czyni to $\mathrm{w}$ taki sposób, aby jego słowa nie raziły niepowściągliwością, choć nie odnosi w tym przypadku zbyt wielkiego sukcesu. Mimo bowiem dostrzegalnych starań ze strony Rosenzweiga jego opis ludzkiej, powiedzmy, „miłości” jest - w mojej ocenie - nadmiernie naturalistyczny. Dzieje się tak, jak sądzę, nie tylko z winy autora Gwiazdy, ale wynika to z samego tematu podjętej refleksji. Miłość, przejawiająca się - także - jako erotyczna namiętność, jest przecież niewyrażalna w żadnym języku, pozostając właśnie głęboko skrywaną „tajemnicą”, dziwnym fenomenem umykającym poznaniu i nazwaniu, zwłaszcza wtedy, kiedy fizycznym doznaniom towarzyszy pewien element „nadzmysłowości”, implikowanej choćby w delikatności, troskliwości czy szacunku, a seksualne pożądanie nie jest motywowane jedynie przez biologiczny popęd, możliwy do zaspokojenia, przynajmniej teoretycznie, bez udziału osoby wybranej, wyjątkowej lub po prostu „miłowanej” przez „kochającego”. Rosenzweig spogląda jednak na tę kwestię odmiennie, do pewnego stopnia ją chyba upraszczając:

To miłość spełnia wszystkie wymagania postawione tu pojęciu Objawiciela; miłość kochającego, a nie ukochanej. Tylko miłość kochającego jest tym, wciąż odnawianym, samopoświęceniem. Jedynie on oddaje siebie w miłości. Ukochana przyjmuje podarunek. To przyjęcie jest jej własnym darem.

49 Zohar II, 144: 1-2. Cyt za: R. Elior, Jewish Mysticism. The Infinite Expression of Freedom, Littman Library of Jewish Civilization, Oxford, Portland, OR 2007, s. 48, tłum. własne. 
Lecz przyjmując go, pozostaje u siebie i staje się w pełni spokojną i szczęśliwą w sobie duszą. A kochający wydobywa swą miłość z pnia swojej Sobości, jak drzewo wypuszczające gałęzie. Każdy konar odrywa się od pnia i wypierając się go, już o nim więcej nie pamięta. Ale drzewo stoi tu, przystrojone swymi konarami, które do niego należą. Choćby każdy z nich mu zaprzeczał ${ }^{50}$.

Muszę wyznać, że - choć rozumiem dosłowny sens przywołanego fragmentu - nie mam najmniejszej ochoty na ten temat pisać ${ }^{51}$. Nie chciałabym dodatkowo wulgaryzować tego, co powinno pozostać „tajemnicą”, bo „bardzo jest święte”52. Mogę natomiast niejako na marginesie zauważyć, że powyższa wypowiedź Rosenzweiga, w jej literalnym znaczeniu, doskonale wpisuje się w nurt patriarchalnej narracji dyskredytującej kobiety. W tym przypadku są one postrzegane jako istoty pozostające pasywnym i receptywnym obiektem aktów seksualnych, których wyłącznymi podmiotami są mężczyźni. Akty te mają stanowić według Rosenzweiga wyraz „samopoświęcenia się” mężczyzn zapewniających w ten sposób spokój i szczęście kobietom. Pogląd ten, w mojej opinii, jest nie tylko niedorzeczny, lecz nawet perwersyjny. Oczywiście nie wykluczam, że istnieją kobiety podzielające zdanie Rosenzweiga. Być może lubią być uprzedmiotowione i czują się niezwykle usatysfakcjonowane w sytuacji, kiedy „kochający” mężczyźni bardzo się dla nich „poświęcają”, składając im swoje „podarunki” i nie oczekując - jakoby - niczego w zamian. O gustach się jednak nie dyskutuje i raczej nie wolno o nich dyskutować, szczególnie gdy odnoszą się do jednego z najbardziej intymnych wymiarów ludzkiej egzystencji. Z drugiej strony, w kontekście „samopoświęcenia kochającego", wydaje się niejasne twierdzenie Rosenzweiga, że tylko kobieta, zwłaszcza „najbardziej kobieca” - a nie „żaden mężczyzna” - jest w stanie „umrzeć z miłości”, mając zresztą do tego pełne prawo, gwarantowane przez „naturę" ${ }^{3}$. Można by w tym momencie rzucić ironicznie „na szczęście”,

$50 \quad$ F. Rosenzweig, Gwiazda zbawienia, dz. cyt., s. 275.

51 Zainteresowanych niniejszą kwestią odsyłam do tekstu francuskojęzycznego rabina i filozofa, Marca-Alaina Ouaknina, który bez większego skrępowania - a właściwie bez żadnego skrępowania - wyjaśnia peszat, czyli dosłowny sens, „dawania” i „otrzymywania”, dosyć brutalnie odzierając „tajemnicę” z całej jej tajemniczości. Por. M.A. Ouaknin, Tajemnice kabały, dz. cyt., s. 120.

52 „Wśród wielkiej miłości/ Wszystko jest poczęte/ I wszystko - bez sensu/ - Lecz bardzo jest święte". Słowa te pochodzą z elegii Jarosława Iwaszkiewicza, pt. Piosenka dla zmartej, którą na swój prywatny użytek określam jako „poemat orficko-kabalistyczny” (J. Iwaszkiewicz, Piosenka dla zmarłej, w: tegoż, Wiersze, t. 1, Czytelnik, Warszawa 1977, s. 416 i nn.).

53 F. Rosenzweig, Gwiazda zbawienia, dz. cyt., s. 267. 
jak również dodać, iż zapewne byłoby znacznie gorzej, gdyby „kobieca kobieta” umierała $\mathrm{z}$ miłości, nie mając do tego prawa. $\mathrm{W}$ takim przypadku, jak podejrzewam, śmierć „ukochanej” świadczyłaby o godnej potępienia transgresji norm moralnych.

Zupełnie inaczej natomiast, a także z większą powagą, należy odczytywać słowa Rosenzweiga, jeżeli interpretujemy ich sens naddany. Nabierają wówczas naprawdę głębokiego znaczenia. Filozof prezentuje bowiem w przywołanym tekście szczególną koncepcję „Objawiciela” - „Ofiarodawcy”, czyli Boga, który „oddaje siebie” - sam siebie udziela, czyniąc to z miłości do przedmiotu swojego uczucia. Jednocześnie „kochający Objawiciel” „wypiera się” samego siebie oraz samego siebie „zaprzecza”, dokonując autonegacji. W tym momencie można już bez większego trudu ustalić genezę myśli Rosenzweiga, który nawiązuje w tekście Gwiazdy do mistycznej doktryny, zawierającej koncepcję צמצום (cimcum) - retrakcji, regresji oraz שפע (szefa) - emanacji, pozostających, według kabalistów, pod wpływem oddziaływania siły dośrodkowej - הסתלקות (histalkut) i odśrodkowej - התפשטות $(\text { hitpasztut })^{54}$. Aby nie być gołosłowną, posłużę się tutaj precyzyjnym opisem Gershoma Scholema, wskazującego na silnie wyrażony dualizm oraz dynamizm, charakteryzujące proces stwarzania, przedstawiany przez kabalistów:

Wycofanie i emanacja są dwiema zasadami, dzięki którym Bóg objawia się jako Stwórca. Zasady te działają i wzajemnie na siebie oddziałują na każdym etapie procesu stwarzania. [...] Każda [jednostkowa] egzystencja zakłada dialektyczny, dwutorowy ruch; nic nie staje się bytem za pośrednictwem jednokierunkowego działania. Wszystko istnieje dzięki kombinacji wycofania się oraz emanacji. Rytm żyjącego Boga [...] może być opisany jako podwójny proces wdychania i wydychania. [...] Podwójny rytm regresji i wypływu jest podstawą wszystkiego, co istnieje ${ }^{55}$.

Dopiero w takim kontekście można pojąć prawdziwy sens sformułowanego w Pieśni nad Pieśniami i wykorzystanego przez Rosenzweiga twierdzenia, że miłość jest „potężna jak śmierć" ${ }^{26}$, które de facto oznacza, iż miłość powoduje

54 Por. G. Scholem, Mistycyzm żydowski i jego główne kierunki, tłum. I. Kania, Wydawnictwo Aletheia, Warszawa 2007, s. 292.

55 Idem, Sabbatai Sevi: The Mystical Messiah, Princeton University Press, Princeton, NJ 1973, s. 31, tłum. własne.

56 „Połóż mię jak pieczęć na twoim sercu, jak pieczęć na twoim ramieniu, bo jak śmierć potężna jest miłość, zazdrość jej nieprzejednana jak Szeol, żar jej to żar ognia, płomień Pański” (Pnp 8, 6). 
śmierć, bądź raczej że jest ona przyczyną ciągłego i stałego umierania - podmiotowej autodestrukcji, następującej w przebiegu oddziaływania uczucia nie tylko warunkującego kreację, lecz również wyniszczającego.

Tak więc na etapie cimcum oraz szefa następuje najbardziej dramatyczny moment trwających dziejów Boga, człowieka i świata. Bóstwo kwestionuje i niszczy samo siebie, aby mogło zaistnieć to, co skończone. Jakiś element boskości wciąż zanika i ginie. Właśnie z tego powodu, zauważa Rosenzweig, boskie i „władcze Nie” - wyłonione z pierwotnie nieskończonej Nicości - „nosi blizny walki, w której się wyłoniło" ${ }^{57}$. Jeżeli blizny są śladami ran, a rany świadczą o doznanym lub doznawanym cierpieniu, oznacza to, że proces przekształcania się Nieskończonego $\mathrm{w}$ skończone jest bolesny, przeżywany przez bóstwo $\mathrm{w}$ „nieskończonym czasie" ${ }^{58}$ i w każdej chwili, ponieważ w każdej chwili, zdaniem Rosenzweiga, wydarza się - bez potrzeby, przyczyny, uzasadnienia czy motywu - zawsze „teraźniejsza" miłość.

\section{Koncepcja Nicości i Bytu w Gwieździe zbawienia}

Jedynie o Bogu wolno powiedzieć, że jest Nicością ${ }^{59}$.

Franz Rosenzweig

Franz Rosenzweig prezentuje w Gwieździe zbawienia szczególną koncepcję Nicości, która jest jedną $\mathrm{z}$ ważnych idei pojawiających się w tym dziele. Filozof stara się zatem zdefiniować Nicość, podkreślając, że nie należy utożsamiać jej z „niczym”, oznaczającym niebyt lub zero ${ }^{60}$. Wręcz przeciwnie, skoro „o Bogu wolno powiedzieć, że jest Nicością” i jeżeli o Bogu wolno powiedzieć, że „jest prawdą" ${ }^{\prime \prime}$, to można również sformułować zdanie: „Nicość jest prawdą”. Prawdziwy jest więc pewien byt będący „Nie-Czymś” albo „Czymś” niepodobnym do czegokolwiek innego ${ }^{62}$. Chociaż nie posiada desygnatu dostępnego ludzkiemu poznaniu, bytuje w sensie pełnym.

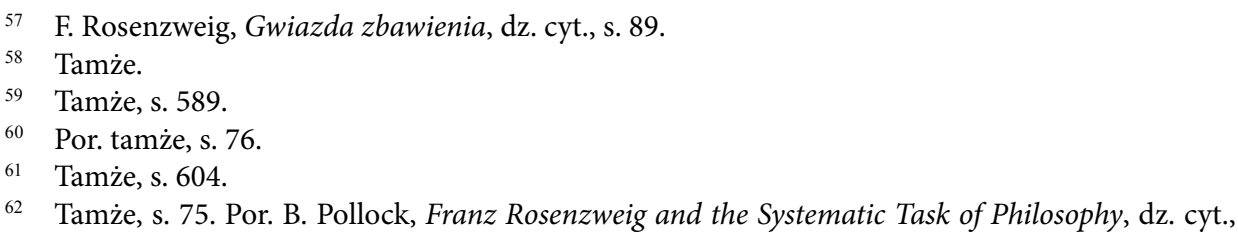


Mimo że koncepcja Nicości zaprezentowana przez Rosenzweiga jest interesująca, to, w moim odczuciu, stanowi po prostu współczesną „wariację na temat" אין (ajin), boskiej i świętej Nicości ${ }^{63}$. W myśli kabalistycznej ajin jest takכתe terminem odnoszącym się do najwyższej sefiry Drzewa Życia - Korony, כתר $(k e t e r)^{64}$, której - podobnie jak Nicości - nie można opisać lub wyrazić. Sefira ta, co istotne, reprezentuje לציו (racon) - wolę Nieskończonego oraz Jego pragnienie tworzenia i dawania. Stanowi pierwotne źródło wszelkiej aktywności związanej z kreacją. Nie jest ani intelligibilna, ani tym bardziej poznawalna empirycznie. Pozostaje w ukryciu, „wewnątrz” najwyższego Emanatora. Ajin ma także ścisły związek z wymiarem tego, co Nieskończone, czyli z סוף אין (Ein-Sof) - bezkresną, bezkształtną i chaotyczną boskością „samą w sobie” - istniejącą przed jej objawieniem się w skończonym stworzeniu. Tę koncepcję bardzo jasno przedstawia właśnie Rosenzweig:

Każda nowa istota jest nowym zaprzeczeniem Nicości, czymś nigdy nieistniejącym, początkiem dla samego siebie, czymś niesłychanym, „nowym pod słońcem”. Siła zaprzeczania Nicości jest tu nieskończona, ale skończone jest każde poszczególne działanie tej siły; nieskończona obfitość, skończony obraz. Poszczególne zjawiska wznoszą się z nocy bez podstawy i kierunku ${ }^{65}$.

Nicość zatem - siłą swojej woli - samą siebie zaprzecza, czy też siebie neguje, wypowiadając słowo „Nie”66. Z Nicości także wypływa „potwierdzenie” dla aktu kreacji, czyli boskie „Tak”" Nicość również powoduje, że z Ein-Sof, „nieskończonej obfitości” albo „nocy bez podstawy i kierunku”, wyłaniają się odrębne od siebie byty skończone. Jednocześnie reprezentująca ajin sefira keter łączy, ze względu na swoje położenie, Nieskończoność z mądrością Absolutu, reprezentowaną przez sefirę חכמה (chochma) ${ }^{68}$, a więc z „logosem świata"69, przejawiającym

\section{s. 140 .}

63 Por. D.A. Crosby, Faith and Reason: Their Roles in Religious and Secular Life, State University of New York Press, Albany, NY 2011, s. 122.

64 Por. I. Schochet, Two Systems of Ten Sefirot, https://link.do/tXQNl, [dostęp: 3.05.2019].

65 F. Rosenzweig, Gwiazda zbawienia, dz. cyt., s. 111.

66 Tamże, s. 88.

67 Tamże, s. 87.

68 Por. G. Scholem, Mistycyzm żydowski i jego główne kierunki, dz. cyt., s. 243n.

69 Jak słusznie zauważa Mosze Idel, w ujęciu kabalistycznym nieskończona boskość znajduje się tak ponad kategorią Bytu, jak również ponad kategorią Nie-bytu: „In Kabbalah, The Infinite is above the 'Naught', that is above the Sefirah Keter, and above 'Being', or the Sefirah Hokhmah 
się w „nieskończoności potwierdzanej Nie-nicości”70. Jednocześnie Rosenzweig akcentuje wolitywny aspekt aktów kreacji. Twierdzi, podobnie jak czynili i czynią to kabaliści, że praprzyczyną stwarzania jest właśnie racon, a także immanentna wolność Boga będącego Nicością, która powoduje, że Bóg pragnie sam siebie, czyli swoją nieskończoność negować, aby mógł (za)istnieć świat składający się z konkretnych indywiduów - bytów jednostkowych. Ich egzystencja jest każdorazowo „chciana” oraz potwierdzana przez wolną do zaprzeczania sobie Nicość pragnącą przekształcać się w Nie-Nicość (Nie-Nie-Coś), przechodzić „ku Czemus'” ${ }^{71}$, co ma się objawić jako byt widzialny ${ }^{72}$, skończony, już nie-boski, jako że od Boga odrębny:

Wolny czyn w Bogu, Coś zjawiającego się w świecie: oba są równie nagłymi, równie jednorazowymi, równie nowymi objawieniami z nocy Nicości; tam z Nicości Boga, tu z Nicości świata. Oba wypływają z twardej walki wręcz Nie z Nicością. Każdy boski czyn, każde ziemskie zjawisko jest nowym zwycięstwem nad Nicością, czymś wspaniałym jak w pierwszym dniu. Lecz kiedy w Bogu bezgraniczna jasność wydobywa się z nocy Nicości, ciemne łono Nicości świata rozrywają barwne, choć same jeszcze ślepe narodziny Czegoś poszczególnego $^{73}$.

Niezależnie więc od tego, jak bardzo Rosenzweig pragnąłby się dystansować od doktryn mistycznych, tak czy inaczej powtarza kabalistyczną i chasydzką koncepcję מאין (jesz me-ajin) - „[kreacji] bytu z Nicości”, która de facto stanowi przecież pleromę - boską pełnię, przy czym pełnia może być także energią. Chociaż autor Gwiazdy zbawienia usiłuje przeciwstawić „Nicość Boga” „Nicości świata”, broniąc autonomii dwóch porządków ontycznych, czyni to w sposób niezupełnie konsekwentny, szczególnie wówczas, kiedy przedstawia swoją koncepcję Dei absconditi - Dei revelati:

Dla Boga Stworzenie nie jest jedynie stworzeniem świata, lecz także czymś, co dzieje się w nim samym jako ukrytym. Dlatego Stworzenie musieliśmy określić jako objawienie się Boga. I rzeczywiście objawia się w nim jak Stwórca,

(wisdom)" (M. Idel, Rosenzweig and Kabbalah, w: red. P. Mendes-Flohr, The Philosophy of Franz Rosenzweig, University Press of New England, Hanover, NH 1988, s. 167).

70 F. Rosenzweig, Gwiazda zbawienia, dz. cyt., s. 109.

71 F. Rosenzweig, Gwiazda zbawienia, dz. cyt., s. 79.

72 Por. E.R. Wolfson, Giving beyond the Gift: Apophasis and Overcoming Theomania, dz. cyt., s. 52.

73 F. Rosenzweig, Gwiazda zbawienia, dz. cyt., s. 112. 
a więc w prawdziwych czynach, które już nie wzrastają, nie powiększają się, lecz są na początku i raz na zawsze. Są zatem tym, co dotyczy Boga, nie czynami, lecz własnościami ${ }^{74}$.

W tym momencie natrafiamy w myśli Rosenzweiga na pewną aporię. Skoro Bóg - bądź własność Boga - objawia się w stworzeniu, oznacza to, że „rzeczywistość Boga” oraz „rzeczywistość świata” w jakiś sposób nakładają się na siebie, posiadając element wspólny lub tożsamy. Staje się to jeszcze wyraźniejsze, gdy Rosenzweig pisze na temat „objawiającej się” i jednocześnie „ukrywającej się” istoty Boga:

Właśnie kiedy się On objawia, ukrywa się. Istota Boga, który by się nie objawił, nie mogłaby pozostać dla nas długo zamknięta. Cóż bowiem ukryje się przed doświadczającym wszystkiego [...], przed poznającym rozumem człowieka? ${ }^{75}$

Według Rosenzweiga Bóg się zatem ukrywa, pragnąc nie zostać dostrzeżonym, rozpoznanym albo zrozumianym przez ludzi. Jednocześnie - podobnie jak w myśli chasydzkiej - stworzony świat ma być miejscem ukrycia boskiej istoty. Z tego powodu niektórzy egzegeci są zdania, że hebrajskie słowo עולם (olam), oznaczające „świat”, wywodzi się od העלם (he’elem), „ukrycia”76. Innymi słowy, według mekubalim Bóg ma się ukrywać przed ludźmi, aby zagwarantować im wolność oraz możliwość podejmowania autonomicznych wyborów i osobistych decyzji ${ }^{77}$.

Ponadto kabaliści podkreślają, że „ukrycie” czy też „zasłonięcie” stanowi warunek objawienia, objawienie zaś warunkuje i przyczynuje „ukrycie” boskiego światła. Ukryta w świecie energia Absolutu ma bowiem ożywiać olam - stworzony świat umożliwiający boskości Jej ekspresję, podobnie jak ma to miejsce w przypadku energii elektrycznej i żarówki. Zastosowanie żarówki jest przecież konieczne, o ile chcielibyśmy oświetlać jakąś przestrzeń, wykorzystując energię elektryczną. Energia ta nie mogłaby się zogniskować, gdyby nie było żarówki, a żarówka nie świeciłaby, gdyby nie aktywizowała jej energia. Inny - starszy przykład stanowi koegzystencja duszy i ciała. Dusza człowieka musi być osło-

\footnotetext{
Tamże, s. 270 i nn.

F. Rosenzweig, Gwiazda zbawienia, dz. cyt., s. 590.

Por. R. Elior, Mistyczne źródła chasydyzmu, tłum. M. Tomal, Austeria, Kraków 2009, s. 203 i 263.

77 Por. Jewish Matters: A Pocketbook of Knowledge and Inspiration, ed. D. Kornbluth, Targum Press, Southfield, MI 1999, s. 53.
} 
nięta przez ciało, dzięki któremu dusza jest w stanie się wyrażać, ukazując swoją wyjątkowość i niepowtarzalność. Jednocześnie ciało potrzebuje duszy, ponieważ bez niej nie miałoby sił witalnych. Ciało i dusza są więc współzależne. W takim ujęciu świat jest właśnie postrzegany jako ukrycie boskiego bytu ten świat ożywiającego. Boski byt $\mathrm{z}$ kolei nie mógłby stwarzać ani podtrzymywać $\mathrm{w}$ istnieniu $\mathrm{w}$ tego, co stworzone, jeżeli nie byłby ukryty.

Tak czy inaczej, należy przyznać, że koncepcja olam - he’elem jest, by tak rzec, teologicznie kłopotliwa, ponieważ jej konsekwencję stanowi negacja Bożej transcendencji, a tym samym przyjęcie idei Boga immanentnego. W literaturze rabinicznej nie podjęto próby rozwiązania tej złożonej kwestii ${ }^{78}$. Mekubalim natomiast usiłowali ją wyjaśniać, chociaż nie byli w stanie zupełnie pokonać problemu, ze względu na zróżnicowane pojmowanie sefirot, których status ontyczny nie jest w myśli kabalistycznej jednoznacznie zdefiniowany. A zatem sefiry mogą być atrybutami Boga, partycypującymi w Jego istocie. Mogą także być emanacjami boskości, przenikającymi to, co stworzone, albo też „naczyniami”, przez które przepływa boska energia i dzięki którym byt absolutny kreuje „widzialną” rzeczywistość ${ }^{79}$. Wyłącznie w tym ostatnim przypadku koncepcja Dei absconditi - Dei revelati nie pociąga za sobą konieczności uznania za prawdziwy poglądu głoszącego immanencję boskości.

Trudno zatem wyjaśnić, $\mathrm{z}$ jakiego powodu Rosenzweig powiela tę panteizującą doktrynę, która raczej nie przystaje do głównych założeń jego myśli. Być może przedstawia ją, zamierzając podkreślić ścisły związek zachodzący pomiędzy procesami stworzenia a objawienia. Jak się jednak wydaje, filozof nie przemyślał wystarczająco dokładnie koncepcji Boga ukrytego w świecie wraz ze wszystkimi jej implikacjami ontologicznymi ${ }^{80}$. Wpłynęło to $\mathrm{w}$ jakiejś mierze destrukcyjnie na spójność postulowanego przez Rosenzweiga „nowego myślenia”, które - moim zdaniem - niezupełnie jest zresztą nowe.

78 Por. B.L. Sherwin, Kabbalah: An Introduction to Jewish Mysticism, Rowman \& Littlefield Publishers, Oxford 2006, s. 57.

79 Por. B.L. Sherwin, Kabbalah: An Introduction to Jewish Mysticism, dz. cyt., s. 58.

80 Problemu Bożej transcendencji negowanej przez doktrynę głoszącą obecność Boga ukrytego w świecie nie rozwiązał $\mathrm{w}$ późniejszym okresie także Hans Jonas, również nawiązujący w swoim dyskursie do myśli kabalistycznej. Por. K. Kornacka, „A Bóg pozwolit, by coś takiego się wydarzyło”. Hansa Jonasa teodycea po Holokauście, „Kwartalnik Filozoficzny” 2013, nr 1, s. 162. 


\section{Zakończenie}

Mistyka to najbardziej narodowy ze wszystkich obszarów judaizmu. ${ }^{81}$

Gershom Scholem

Franz Rosenzweig uczynił naprawdę wiele, aby percepcja jego myśli nie okazała się zbyt prosta. Zwraca przede wszystkim uwagę fakt, że pewne fragmenty Gwiazdy zbawienia są nośnikami różnych znaczeń. Treść dzieła można więc odczytywać i analizować na wielu poziomach, odsłaniając sensy ukryte, w tym również warstwę, którą można nazwać mistyczną. Jej ukazanie przysparza niekiedy problemów, ponieważ filozof raczej unika posługiwania się językiem kabalistów, zastępując ugruntowane $\mathrm{w}$ tradycji pojęcia odmiennymi terminami. Co więcej, w Gwieździe zbawienia autor wyraża swoją zdecydowaną niechęć wobec mistyków i mistyki ${ }^{82}$. Bezpośrednio jednak po śmierci Rosenzweiga zaprzyjaźniony z nim Gershom Scholem napisał, że prezentowana przez filozofa teoria języka, a także wykorzystana przez niego kategoria „myśli uwikłanej w czas” przypominają poglądy „wzgardzonych kabalistów”" Trzeba przyznać, eż Scholem nie pomylił się: właściwie zinterpretował tekst Gwiazdy, mimo że nie przeprowadził pogłębionej analizy dzieła. Rosenzweig przejął bowiem od mekubalim nie tylko ideę „myśli uwikłanej w czas”, lecz także samą koncepcję czasu: ideę przeszłości, która staje się wciąż na nowo aktualizowaną teraźniejszością ${ }^{84}$, a także koncepcję przyszłości ujmowanej w teraźniejszości poprzez antycypację ${ }^{85}$. Pisze również na temat mistycznego eonu zbawienia, הבא העולם (ha-olam ha-ba), określając kabalistyczny „Świat, Który Ma Nadejśćc" jako „wiecznie nadchodzące Królestwo”87.

Szczególnie w ostatnich latach nieliczni badacze myśli Rosenweiga zaczęli wskazywać, że inspiracją dla jego poglądów mogły stać się pewne doktryny kabalistyczne ${ }^{88}$, różne akurat od tych, które przedstawiłam w artykule. Zarazem

${ }_{81}$ G. Scholem, Franz Rosenzweig i jego Gwiazda zbawienia, tłum. E. Zwanowska, w: tegoż, Żydzi i Niemcy. Eseje, listy, rozmowa, tłum. E. Zawanowska, A. Lipszyc, Pogranicze, Sejny 2006, s. 184.

82 Por. F. Rosenzweig, Gwiazda zbawienia, dz. cyt., s. 340 i nn.

83 G. Scholem, Franz Rosenzweig i jego Gwiazda zbawienia, dz. cyt., s. 190.

84 F. Rosenzweig, Gwiazda zbawienia, dz. cyt., s. 215.

85 Tamże, s. 357.

86 Por. M.Ch. Luzzatto, Ścieżka sprawiedliwych, tłum. A. Borowski, Fundacja Ronalda S. Laudera, Kraków 2005, s. 28-31.

87 F. Rosenzweig, Gwiazda zbawienia, dz. cyt., s. 364 i nn.

88 Por. M. Idel, Old Worlds, New Mirrors: On Jewish Mysticism and Twentieth-Century Thought, dz. 
pojawiła się potrzeba uzasadnienia takiej interpretacji. Moszemu Idelowi udało się więc natrafić na skierowany do Hermanna Cohena list potwierdzający zainteresowanie Rosenzweiga kabałą zoharyczną oraz luriańską: quod erat demonstrandum. Elliot R. Wolfson z kolei przywołał w swojej książce słowa pochodzące z listu kabalisty i syjonisty, Abrahama Izaaka Kuka, który w roku 1930 wyraźnie stwierdził, że dostrzega ideowe związki pomiędzy myślą Rosenzweiga a kabałą, dodając, że jego zdaniem Gwiazdę zbawienia zrozumieją wyłącznie ba’alej mistorin, czyli „mistrzowie tajemnic” - osoby posiadające wiedzę na temat ezoterycznych doktryn mistycznych ${ }^{89}$.

Na podstawie powyższych przesłanek, możliwych do określenia jako argumentatio extra causam, zarówno Idel, jak i Wolfson dowodzą, że w „,nowym myśleniu” Rosenzweiga dostrzega się pewne zapożyczenia pochodzące z żydowskiej filozofii kabalistycznej. Tymczasem zapożyczenia te są, moim zdaniem, na tyle liczne, że nie istnieje $\mathrm{w}$ rzeczywistości potrzeba ich zewnętrznego uzasadniania. Oprócz omówionej tutaj mistycznej koncepcji miłości, doktryny jesz me-ajin, czy też idei Boga ukrytego w świecie, filozof wykorzystał w Gwieździe zbawienia inne jeszcze rozwiązania żydowskich mistyków. W tekście dzieła pojawia się na przykład motyw współcierpiącej i tułającej się wraz ze swoim Narodem Szechiny oraz doktryna głosząca istnienie nicocot ${ }^{90}$, czyli „rozproszonych w świecie iskier Bożego pra-światła" ${ }^{\prime \prime}$. Podstawowym natomiast przesłaniem sformułowanym przez filozofa jest konieczność „zbawiania”92 Boga i świata przez „żydowskiego człowieka"93 , niebędąca niczym innym, jak tylko powinnością realizacji kabalistycznych postulatów „jednoczenia Boga” oraz „naprawy świata”94.

Niestety nie byłam w stanie przedstawić wszystkich tych zagadnień na łamach jednego artykułu. Odczuwam mimo wszystko pewne zadowolenie wynikające

cyt., s. 159-167; E.R. Wolfson, Giving beyond the Gift: Apophasis and Overcoming Theomania, dz. cyt., s. 36-39.

„Kook acknowledged the conceptual affinities between Rosenzweig and the kabbalah, and he even went so far to say that those who are not masters of the mysteries (baialei mistorin) will not be able to comprehend his words" (E.R. Wolfson, Giving beyond the Gift: Apophasis and Overcoming Theomania, dz. cyt., s. 36).

Por. M. Idel, Old Worlds, New Mirrors: On Jewish Mysticism and Twentieth-Century Thought, dz. cyt., s. 162.

$91 \quad$ F. Rosenzweig, Gwiazda zbawienia, dz. cyt., s. 636.

92 Por. tamże, s. 636.

93 Tamże, s. 637.

94 W języku kabalistycznym są one opisywane jako jichud Kudsza BerichHu we-Szechinateja oraz tikkun ha-olam. 
z faktu, że podjęłam próbę opisania tego, co z jednej strony wydaje się ważne w myśli Rosenzweiga, $\mathrm{z}$ drugiej zaś jest chyba najtrudniejsze do omówienia: starałam się przecież pisać o „niewyrażalnej” miłości i „nienazywalnej” Nicości, ontologicznie nieprzyczynowanych, „pozbawionych początku” ${ }^{95}$, „wydarzających się" i zarazem trwających, a także warunkujących istnienie uniwersum, chociaż zarówno Nicość, jak i miłość są - ze swojej istoty - nieuwarunkowane i nie stawiają warunków.

\section{Bibliografia}

Bardel M., Mocna jak śmierć. Zagadnienie miłości w antropologii filozoficznej Franza Rosenzweiga, Kraków 2001.

Biblia Tysiąclecia - Pismo Święte Starego i Nowego Testamentu w przekładzie zjęzyków oryginalnych, Poznań, Warszawa 1980.

Crosby D.A., Faith and Reason: Their Roles in Religious and Secular Life, Albany, NY 2011.

Doktór J., Poczatki chasydyzmu polskiego, Toruń 2017.

Drob S.L., The Sefirot: Kabbalistic Archetypes of Mind and Creation, URL: https:// link.do/QGmeI, [dostęp: 25.04.2019].

Elior R., Jewish Mysticism. The Infinite Expression of Freedom, tłum. Y. Nave, A. B. Millman, Oxford, Portland, OR 2007.

Elior R., Między galutem a wyzwoleniem, między rzeczywistościq a kabałą. Esej o chasydyzmie, tłum. D. M. Ben Refael, Poznań 2019.

Elior R., Mistyczne źródła chasydyzmu, tłum. M. Tomal, Kraków 2009.

Glatzer N.N., Franz Rosenzweig: His Life and Thought, Indianapolis, IN, Cambridge, MA 1998.

Guttmann J., Philosophies of Judaism: The History of Jewish Philosophy from Biblical Times t Franz Rosenzweig, tłum. D. W. Silverman, Garden City, NY 1966. Hegel G.W.F., Wykłady z historii filozofii, t. 2, tłum. Ś.F. Nowicki, Warszawa 2013. Idel M., Kabbalah and Eros, New Haven, CT 2005.

Idel M., Old Worlds, New Mirrors: On Jewish Mysticism and Twentieth-Century Thought, Philadelphia, PA 2010.

95 F. Rosenzweig, Gwiazda zbawienia, dz. cyt., s. 239. 
Idel M., Rosenzweig and Kabbalah, w: The Philosophy of Franz Rosenzweig, ed. P. Mendes-Flohr, Hanover, NH 1988, s. 162-171.

Iwaszkiewicz J., Piosenka dla zmarkej, w: tegoż, Wiersze, t. 1, Warszawa 1977, s. $416-417$.

Kornacka K., „A Bóg pozwolit, by coś takiego się wydarzyło”. Hansa Jonasa teodycea po Holokauście, „Kwartalnik Filozoficzny” 2013, nr 1, s. 157-172.

Kornberg-Greenberg Y., Better than Wine: Love, Poetry, and Prayer in the Thought of Franz Rosenzweig, Atlanta, GA 1996.

Jewish Matters: A Pocketbook of Knowledge and Inspiration, ed. D. Kornbluth, Southfield, MI 1999.

Kwiatkowski F., Problem wpływu teozofi Jakuba Böhmego na idealistyczny system Georga Wilhelma Fryderyka Hegla, „Studia z Historii Filozofii” 2016, nr 3(7), s. 55-71.

Langer J., Miłosna mistyka kabały. Światy, słowa, sny, tłum. L. Jerkiewicz, Kraków 2015.

Luzzatto M.Ch., Ścieżka sprawiedliwych, tłum. A. Borowski, Kraków 2005.

Ouaknin M.A., Tajemnice kabały, tłum. K. i K. Pruscy, Warszawa 2006.

Patai R., The Hebrew Goddess, Detroit, MI 1990.

Pollock B., Franz Rosenzweig and the Systematic Task of Philosophy, New York, NY 2014.

Rosenzweig F., Gwiazda zbawienia, tłum. T. Gadacz, Warszawa 2012.

Rosenzweig F., Hegel und der Staat. Herausgegeben von F. Lachmann. Mit einem Nachwort von A. Honneth, Berlin 2010.

Rosenzweig F., Kleinere Schriften, Berlin 1937.

Rosenzweig F., Nowe myślenie. Kilka uwag ex post do Gwiazdy zbawienia, w: tegoż, Gwiazda zbawienia, tłum. T. Gadacz, Warszawa 2012, s. 659-689.

Schochet I., Two Systems of Ten Sefirot, URL: https://link.do/tXQNl, [dostęp: 3.05.2019].

Scholem G., Franz Rosenzweig i jego Gwiazda zbawienia, w: tegoż, Żydzi i Niemcy. Eseje, listy, rozmowa, tłum. E. Zawanowska, A. Lipszyc, Sejny 2006, s. 175196.

Scholem G., Kabała i jej symbolika, tłum. R. Wojnakowski, Warszawa 2014.

Scholem G., Mistycyzm żydowski i jego główne kierunki, tłum. I. Kania, Warszawa 2007.

Scholem G., O mistycznej postaci bóstwa, tłum. A.K. Haas, Warszawa 2010. 
Scholem G., Sabbatai Șevi: The Mystical Messiah, tłum. R.J.Z. Werblowsky, Princeton, NJ 1973.

Sherwin B.L., Kabbalah: An Introduction to Jewish Mysticism, Oxford 2006.

Welz C., Love's Transcendence and the Problem of Theodicy, Tübingen 2008.

Wilder-Menzi D., Introduction, w: Ch. Vital, The Tree of Life. Chayyim Vital's Introduction to the Kabbalah of Isaac Luria: The Palace of Adam Kadmon, tłum. D. Wilder-Menzi, Z. Padeh, New York, NY 2008, s. xvii-lvi.

Wolfson E.R., Giving beyond the Gift: Apophasis and Overcoming Theomania, New York, NY 2014.

\section{Streszczenie}

W artykule podjęto próbę opisania kategorii miłości i Nicości, jak również koncepcji Dei absconditi, przedstawionych przez Franza Rosenzweiga w Gwieździe zbawienia. Analiza dzieła pozwoliła na sformułowanie tezy, że konstruując swój system, Rosenzweig wykorzystał najistotniejsze idee oraz poglądy kosmogoniczne i ontologiczne wyrażane wcześniej przez żydowskich mistyków, a zwłaszcza przez myślicieli reprezentujących kabałę zoharyczną i szkołę luriańską.

Słowa kluczowe: Franz Rosenzweig, kabała, filozofia dialogu, mistycyzm żydowski, ontologia, mistyczna koncepcja miłości, dialektyka Nicości i Bytu, doktryna jesz me-ajin, koncepcja Dei absconditi

\section{Summary}

\section{Echad and Ahava, Ayin and Yesh. Some Concepts of the Kabbalah in The Star of Redemption by Franz Rosenzweig}

The aim of the paper is to describe the categories of love and Nothingness as well as the idea of Deus absconditus, which are presented in The Star of Redemption by Franz Rosenzweig. The analysis of the philosopher's major work makes it possible to formulate a thesis that Rosenzweig adopted the central cosmogonic 
and ontological concepts of Jewish mystics - especially the representatives of the Zoharic Kabbalah and the Lurianic school - while constructing his own "starsystem".

Key words: F. Rosenzweig, F, Kabbalah, philosophy of dialogue, Jewish mysticism, ontology, the mystical concept of love, the dialectics of Nothingness and Being, the doctrine of yesh me-ayin, the idea of Deus absconditus 